\title{
Tolerance of Carrot to Low-rate Preemergent and Postemergent Herbicides
}

\author{
Edmund J. Ogbuchiekwe, Milton E. McGiffen, Jr. ${ }^{1}$, Joe Nunez ${ }^{2}$, and \\ Steven A. Fennimore ${ }^{3}$ \\ Department of Botany and Plant Sciences, University of California, Riverside, \\ CA 92521-0124
}

Additional index words. phytotoxicity, preemergent, postemergent, herbicide evaluation, Daucus carota

Abstract. Preemergent and postemergent herbicides were evaluated in the Mediterranean climate of the southern San Joaquin Valley and the desert climate of the Imperial Valley from 1998 through 2000 . Sixteen herbicide treatments were applied both as preemergence (PRE) and postemergence (POST) applications to carrot (Daucus carota L.). Carrot was generally more tolerant to PRE herbicide applications than to POST applications. Carrot was tolerant to PRE and POST imazamox and triflusulfuron at both locations. Carrot root losses due to herbicide were consistent with visual ratings. Treatments that injured carrot tops early in the growing season did not always reduce yield at the end of the season. PRE applications of imazamox and triflusulfuron did not affect carrot tops or the number or weight of marketable carrots. Carrots grown in the Imperial Valley and in the San Joaquin Valley were tolerant to PRE applications of carfentrazone, sulfentrazone, and imazamox. Results were similar for POST applications, although carfentrazone slightly injured carrot roots. PRE application of herbicides increased forked roots more than POST. Chemical names used: $\alpha$, 2-dichloro-5-[4-(difluoromethyl)-4,5-dihydro-3-methyl5-oxo-1H-1, 2,4-triazol-1-yl]-4-fluorobenzenepropanoic acid (carfentrazone); $N$-[2,4-dichloro-5-[4-(difluoromethyl)-4,5-dihydro-3-methyl-5-oxo-1H-1,2,4-triazol-1-yl]phenyl]me thanesulfonamide (sulfentrazone); $N$-(2 carbomethoxy-6-chlorophenyl)-5-ethoxy-7-fluoro $(1,2,4)$ triazolo-[1, 5-c] pyrimidine-2-sulfonamide (cloransulam-methyl); 2-chloro- $N$-[(1methyl-2-methoxy)ethyl]- $N$-(2,4-dimethyl-thein-3-yl)-acetamide (dimethenamid); (2-[4,5dihydro-4-methyl-4-(1-methylethyl)-5-oxo-1H-imidazol-2-yl]-5-(methoxymethyl)-3-pyridinecarboxylic acid) (imazamox); 3-chloro-5-[[[[(4,6-dimethoxy-2-pyrimidinyl) amino] carbonyl] amino] sulfonyl]-1-methyl-1H-pyrazole-4-carboxylic acid (halosulfuron); $\mathrm{N}$ [[(4,6-dimethoxy-2-pyrimidinyl)amino $]$ carbonyl $]$-3-(ethylsulfonyl)-2-pyridinesulfonamide (rimsulfuron); (methyl 2[[[[[4-(dimethylamino)-6-[2,2,2-trifluoroethoxy)-1,3,5-triazin-2-yl] amino] carbonyl] amino] sulfonyl]-3-methylbenzoate) (triflusulfuron).

In 2000, U.S. fresh market carrot was planted on 44,012 ha and produced 1,466,827 metric tons at a value of $\$ 401,176,000$ (USDA, 2001). Fifty-nine percent of the U.S. crop is produced in California, and large acreages are also found in Georgia, Minnesota, and Colorado. California growers planted 35,020 ha of carrots (up from 23,473 ha in 1993), and harvested 1,128 tons, valued at more than $\$ 336$ million. The five main carrot-producing regions in California are the San Joaquin Valley (Kern County), Cuyama Valley (eastern San Luis Obispo and western Kern County), the low desert (Imperial and Riverside Counties), high desert (Los Angeles County), and the central

Received for publication 15 Nov. 2002. Accepted for publication 8 May 2003. Our research was funded by grants from the California Fresh Carrot Advisory Board and the USDA. Susana Aparicio, John Masiunas, and Thomas Lanini reviewed an earlier draft of this manuscript.

${ }^{1}$ To whom reprint requests should be addressed. E-mail: milt@ucr.edu

${ }^{2}$ Univ. of California Cooperative Extension, Kern County, 1031 S. Mt. Vernon Ave., Bakersfield, CA 93307.

${ }^{3}$ Univ. of California, U.S. Agricultural Research Station, 1636 East Alisal St., Salinas, CA 93905. coast (Monterey County). Kern County is the state's largest producer with $75 \%$ of the acreage (USDA, 2000a).

Weeds are a constant problem in carrot production. Carrot is a poor competitor and sensitive to weeds (Stall et al., 2000). The high planting density limits the use of cultivation for carrot weed control, and herbicides are essential for production of carrots (Bell et al., 2000a). Carrot growers have long relied on three very effective chemicals for weed control: metham, linuron, and trifluralin (USDA, 2000b). However, recent legislation threatens to eliminate one or more of these herbicides. The Food Quality Protection Act (FQPA) of 1996 requires the U.S. Environmental Protection Agency (USEPA) to reassess all pesticide tolerances by 2006. The FQPA may result in use restrictions, loss of crop tolerances, or requirements for costly environmental monitoring studies that will lead to the loss of herbicides (Bell et al., 2000b). Weed control programs in low-hectarage crops such as carrots will require weed control options (USDA, 2000b) if pesticide producers decide not to reinvest in linuron, trifluralin, and other older, lower profit herbicides in order to protect them in FQPA-mandated reviews (Bell et al., 2000a).
EPA's reassessment could potentially eliminate the herbicides carrot growers have depended upon for years.

In the past 20 years, few new herbicides have been registered for use in vegetable crops. However, numerous new weed control tools have become available in corn and other major crops. Many of these new herbicides are active at rates of grams per hectare, rather than the kilograms per hectare rates of most of the herbicides currently used in vegetable crops. Low-rate herbicides leave little or no residue and have less groundwater and other off-target impacts than older, high-rate herbicides (Bell et al., 2000b).

The federally funded IR-4 program has helped register pesticides for vegetables and other "minor" crops since the early 1960s. Recognizing that FQPA could potentially create deficiencies in weed control programs of many crops as pesticide registrations are withdrawn, IR-4 has begun to work toward registering newer herbicides. Another example of a program that sponsors research to identify new herbicides for at-risk crops is the USDA's Pest Management Alternative Program. A major agricultural policy goal has been a reduction in the amount of pesticides applied. Herbicides constitute $60 \%$ of the pesticide tonnage applied annually in the United States (USDA, 2000b). The registration of low-usage rate, environmentally favorable herbicides for vegetables would provide growers with a sounder and more stable basis for vegetable weed control programs. The objective of this study was to identify new potential herbicides for fresh carrot growers.

\section{Material and Methods}

Carrots (Caropak) were planted in commercial fields in the San Joaquin Valley on 24 Aug. 1998 and 11 Aug. 1999 and in the Imperial Valley on 19 Oct. 1998 and 7 Oct. 1999. These sites were selected because their soil types, climate, and irrigation systems are representative of two important carrot-producing areas, the San Joaquin Valley and the low desert. Carrot was sprinkler-irrigated in the San Joaquin Valley and furrow-irrigated in the Imperial Valley. The San Joaquin Valley has a Mediterranean climate, with winter rains and dry summers. The Imperial Valley has a windy, arid climate with high sunlight and temperature. Mean temperatures from planting to harvest in the San Joaquin Valley were a maximum of $36{ }^{\circ} \mathrm{C}$ and a minimum $0{ }^{\circ} \mathrm{C}$ in 1998 and $33{ }^{\circ} \mathrm{C}$ maximum and $2{ }^{\circ} \mathrm{C}$ minimum in 1999. In the Imperial Valley, the mean temperatures were $33^{\circ} \mathrm{C}$ maximum and $3{ }^{\circ} \mathrm{C}$ minimum in 1998 , and $35^{\circ} \mathrm{C}$ maximum and $2{ }^{\circ} \mathrm{C}$ in 1999 (Table 1 ).

Rainfall differed dramatically between the Imperial and San Joaquin experimental sites. The highest monthly rainfall recorded in 1998 from planting to harvest was $66 \mathrm{~mm}$ for San Joaquin Valley and $11 \mathrm{~mm}$ in Imperial Valley. In 1999, the highest rainfall was 56 and $9 \mathrm{~mm}$, respectively (Table 1 ).

Soils at the Imperial Valley experimental sites were Imperial-Glenbar clay loam (fine- 
Pest Management

Table 1. Monthly rainfall and average temperature data for San Joaquin Valley (Kern) and Imperial County (Imperial) from the time of planting to the carrot harvest in 1998 and 1999.

\begin{tabular}{|c|c|c|c|c|c|c|c|c|c|c|c|c|}
\hline \multirow[b]{3}{*}{ Month } & \multicolumn{4}{|c|}{ Total precipitation $(\mathrm{mm})$} & \multicolumn{4}{|c|}{ Avg min temp $\left({ }^{\circ} \mathrm{C}\right)$} & \multicolumn{4}{|c|}{ Avg max temp $\left({ }^{\circ} \mathrm{C}\right)$} \\
\hline & \multicolumn{2}{|c|}{1998} & \multicolumn{2}{|c|}{1999} & \multicolumn{2}{|c|}{1998} & \multicolumn{2}{|c|}{1999} & \multicolumn{2}{|c|}{1998} & \multicolumn{2}{|c|}{1999} \\
\hline & $\overline{\text { Kern }}$ & $\overline{\text { Imperial }}$ & Kern & $\overline{\text { Imperial }}$ & Kern & Imperial & Kern & $\overline{\text { Imperial }}$ & $\overline{\text { Kern }}$ & Imperial & $\overline{\text { Kern }}$ & Imperial \\
\hline August & 0.00 & -- & 0.00 & -- & 14.00 & --- & 15.00 & & 36.00 & -- & 33.00 & --- \\
\hline September & 2.00 & --- & 7.00 & --- & 14.00 & --- & 13.00 & & 31.00 & --- & 32.00 & --- \\
\hline October & 25.00 & 2.00 & 5.00 & 0.00 & 9.00 & 13.00 & 10.00 & 12.00 & 24.00 & 33.00 & 28.00 & 35.00 \\
\hline November & 66.00 & 3.00 & 50.00 & 2.00 & 7.00 & 7.00 & 7.00 & 7.00 & 17.00 & 27.00 & 22.00 & 27.00 \\
\hline December & 27.00 & 6.00 & 5.00 & 2.00 & 0.00 & 3.00 & 2.00 & 2.00 & 13.00 & 22.00 & 17.00 & 21.00 \\
\hline February & --- & 5.00 & --- & 9.00 & --- & 4.00 & --- & 6.00 & --- & 23.00 & --- & 22.00 \\
\hline March & --- & 4.00 & --- & 9.00 & --- & 6.00 & --- & 7.00 & --- & 25.00 & --- & 25.00 \\
\hline April & --- & 11.00 & --- & 1.00 & --- & 8.00 & --- & 8.00 & --- & 16.00 & --- & 33.00 \\
\hline
\end{tabular}

Table 2. The effect of rates and timing of different herbicides on carrot (Caropak) injury and yield in San Joaquin Valley in 1998. Applications were made after carrot planting (PRE) or after seedling emergence and establishment (POST). Injury was recorded on a visual scale of 0 to 10 , where $0=$ no crop damage and $10=$ death of carrot plant.

\begin{tabular}{|c|c|c|c|c|c|c|c|c|c|c|c|}
\hline \multirow[b]{4}{*}{ Treatment } & \multirow{4}{*}{$\begin{array}{c}\text { Rate } \\
\left(\mathrm{g} \cdot \mathrm{ha}^{-1} \text { a.i. }\right)\end{array}$} & & & & & \multicolumn{6}{|c|}{ Carrot yield } \\
\hline & & \multicolumn{4}{|c|}{ Weeks after treatment } & \multirow{2}{*}{\multicolumn{2}{|c|}{$\begin{array}{c}\text { Top wt } \\
\left(\mathrm{t} \cdot \mathrm{h}^{-1}\right)\end{array}$}} & \multirow{2}{*}{\multicolumn{2}{|c|}{$\begin{array}{c}\text { No. of marketable } \\
\left(\mathrm{M}^{2}\right)\end{array}$}} & \multirow{2}{*}{\multicolumn{2}{|c|}{$\begin{array}{c}\text { Marketable wt } \\
\left(\mathrm{t} \cdot \mathrm{ha}^{-1}\right)\end{array}$}} \\
\hline & & \multicolumn{2}{|c|}{4 weeks } & \multicolumn{2}{|c|}{8 weeks } & & & & & & \\
\hline & & PRE & POST & PRE & POST & PRE & POST & $\overline{\text { PRE }}$ & POST & PRE & POST \\
\hline Control & N/A & 0.0 & 0.0 & 0.0 & 0.0 & 3.7 & 3.7 & 64.8 & 64.8 & 10.7 & 10.7 \\
\hline Carfentrazone & 11.3 & 0.0 & 6.8 & 0.0 & 2.8 & 3.2 & 2.5 & 51.8 & 35.8 & 8.1 & 6.2 \\
\hline Carfentrazone & 22.7 & 0.0 & 8.3 & 0.0 & 5.3 & 3.5 & 2.1 & 69.5 & 27.0 & 11.1 & 5.2 \\
\hline Sulfentrazone & 43.1 & 3.1 & 4.3 & 1.8 & 2.3 & 2.7 & 2.9 & 37.5 & 37.5 & 7.5 & 7.6 \\
\hline Sulfentrazone & 86.2 & 5.8 & 7.0 & 3.5 & 5.5 & 2.5 & 1.9 & 31.5 & 26.5 & 6.0 & 5.0 \\
\hline Cloransulam & 9.1 & 4.0 & 9.1 & 2.0 & 7.0 & 2.3 & 1.1 & 3.3 & 4.0 & 0.7 & 0. \\
\hline Cloransulam & 18.1 & 6.5 & 9.4 & 4.3 & 8.8 & 1.4 & 0.4 & 0.0 & 0.0 & 0.0 & 0.0 \\
\hline Dimethenamid & 425.5 & 0.0 & 4.0 & 0.0 & 5.3 & 3.7 & 2.0 & 51.8 & 22.8 & 8.8 & 4.1 \\
\hline Dimethenamid & 530.7 & 1.4 & 5.0 & 0.4 & 6.0 & 3.6 & 1.5 & 22.5 & 12.0 & 3.6 & 2.1 \\
\hline Imazamox & 3.6 & 0.0 & 1.8 & 0.0 & 1.0 & 3.7 & 3.3 & 54.5 & 51.3 & 10.9 & 9.2 \\
\hline Imazamox & 7.3 & 0.8 & 3.5 & 0.0 & 0.8 & 3.2 & 3.1 & 41.5 & 48.5 & 7.4 & 7.4 \\
\hline Halosulfuron & 14.5 & 5.8 & 9.1 & 3.3 & 9.3 & 2.9 & 0.3 & 19.8 & 0.3 & 3.5 & 0.1 \\
\hline Halosulfuron & 21.3 & 7.4 & 9.6 & 5.0 & 10.0 & 2.2 & 0.0 & 8.3 & 0.0 & 1.4 & 0.0 \\
\hline Rimsulfuron & 7.3 & 0.5 & 8.0 & 0.0 & 5.5 & 3.0 & 1.9 & 24.5 & 21.0 & 5.4 & 4.1 \\
\hline Rimsulfuron & 14.1 & 1.0 & 9.5 & 0.0 & 7.5 & 3.6 & 1.0 & 30.0 & 8.5 & 5.4 & 1.4 \\
\hline Triflusulfuron & 7.3 & 0.0 & 6.5 & 0.0 & 3.0 & 3.4 & 2.7 & 53.5 & 31.5 & 10.0 & 5.2 \\
\hline Trifusulfuron & 14.1 & 0.6 & 7.3 & 0.0 & 3.8 & 3.4 & 2.8 & 39.8 & 26.5 & 7.3 & 4.2 \\
\hline LSD @ $\alpha=0.05$ & N/A & 0.4 & 0.4 & 0.3 & 0.4 & 0.2 & 0.2 & 3.4 & 2.5 & 0.5 & 0.4 \\
\hline
\end{tabular}

Table 3. The effect of rates and timing of different herbicides on carrot (Caropak) injury and yield in San Joaquin Valley in 1999. Applications were made after carrot planting (PRE) or after seedling emergence and establishment (POST). Injury was recorded on a visual scale of 0 to 10 , where $0=$ no crop damage, and $10=$ death of carrot plant.

\begin{tabular}{|c|c|c|c|c|c|c|c|c|c|c|c|}
\hline \multirow[b]{4}{*}{ Treatment } & \multirow{4}{*}{$\begin{array}{c}\text { Rate } \\
\left(\mathrm{g} \cdot \mathrm{ha}^{-1} \text { a.i. }\right)\end{array}$} & & & & & \multicolumn{6}{|c|}{ Carrot yield } \\
\hline & & \multicolumn{4}{|c|}{ Weeks after treatment } & \multirow{2}{*}{\multicolumn{2}{|c|}{$\begin{array}{c}\text { Top wt } \\
\left(t \cdot h^{-1}\right)\end{array}$}} & \multirow{2}{*}{\multicolumn{2}{|c|}{$\begin{array}{c}\text { No. of marketable } \\
\left(\mathrm{M}^{2}\right)\end{array}$}} & \multirow{2}{*}{\multicolumn{2}{|c|}{$\begin{array}{c}\text { Marketable wt } \\
\left(\mathrm{t} \cdot \mathrm{ha}^{-1}\right)\end{array}$}} \\
\hline & & \multicolumn{2}{|c|}{4 weeks } & \multicolumn{2}{|c|}{8 weeks } & & & & & & \\
\hline & & PRE & $\overline{\text { POST }}$ & PRE & POST & PRE & POST & PRE & POST & PRE & POST \\
\hline Control & N/A & 0.0 & 0.0 & 0.0 & 0.0 & 4.1 & 4.2 & 53.8 & 39.0 & 7.1 & 5.6 \\
\hline Carfentrazone & 11.3 & 0.5 & 10.0 & 0.2 & 9.0 & 4.8 & 0.2 & 31.5 & 1.5 & 4.9 & 0.3 \\
\hline Carfentrazone & 22.7 & 0.7 & 10.0 & 0.7 & 9.8 & 3.5 & 0.0 & 31.3 & 0.0 & 5.0 & 0.0 \\
\hline Sulfentrazone & 43.1 & 5.3 & 7.3 & 3.2 & 5.5 & 3.4 & 2.1 & 28.3 & 22.5 & 4.1 & 4.1 \\
\hline Sulfentrazone & 86.2 & 7.3 & 8.0 & 6.8 & 6.8 & 1.5 & 1.4 & 9.5 & 15.5 & 1.7 & 2.7 \\
\hline Cloransulam & 9.1 & 10.0 & 7.5 & 9.3 & 5.1 & 0.2 & 2.1 & 0.0 & 30.0 & 0.0 & 4.3 \\
\hline Cloransulam & 18.1 & 9.3 & 8.3 & 9.0 & 7.3 & 0.2 & 1.3 & 0.0 & 20.3 & 0.0 & 3.0 \\
\hline Dimethenamid & 425.5 & 8.5 & 6.3 & 8.5 & 5.5 & 0.7 & 3.2 & 0.5 & 24.0 & 0.1 & 4.0 \\
\hline Dimethenamid & 530.7 & 8.8 & 6.8 & 8.3 & 5.5 & 0.6 & 2.5 & 0.3 & 21.0 & 0.0 & 3.3 \\
\hline Imazamox & 3.6 & 0.0 & 0.5 & 0.0 & 0.0 & 4.1 & 4.4 & 40.0 & 38.3 & 6.0 & 5.7 \\
\hline Imazamox & 7.3 & 0.0 & 2.0 & 0.0 & 0.3 & 4.2 & 4.1 & 48.8 & 41.0 & 6.7 & 5.8 \\
\hline Halosulfuron & 14.5 & 10.0 & 8.3 & 10.0 & 7.5 & 0.0 & 2.9 & 0.0 & 18.0 & 0.0 & 2.8 \\
\hline Halosulfuron & 21.3 & 9.8 & 8.3 & 9.5 & 8.3 & 0.1 & 0.8 & 0.0 & 12.5 & 0.0 & 2.3 \\
\hline Rimsulfuron & 7.3 & 7.5 & 7.0 & 7.0 & 3.0 & 1.7 & 2.8 & 7.0 & 33.3 & 0.5 & 5.2 \\
\hline Rimsulfuron & 14.1 & 9.5 & 7.8 & 9.0 & 6.5 & 0.4 & 2.2 & 0.0 & 14.3 & 0.0 & 2.7 \\
\hline Triflusulfuron & 7.3 & 0.0 & 3.8 & 0.0 & 0.8 & 5.0 & 4.0 & 41.0 & 35.8 & 7.0 & 7.2 \\
\hline Trifusulfuron & 14.1 & 0.3 & 7.0 & 0.0 & 2.1 & 3.8 & 3.6 & 38.5 & 34.5 & 5.7 & 5.1 \\
\hline LSD @ $\alpha=0.05$ & N/A & 1.2 & 1.7 & 1.3 & 1.6 & 1.1 & 1.3 & 12.4 & 15.2 & 1.5 & 2.6 \\
\hline
\end{tabular}

silty, mixed calcareous, hyperthermic Typic Torrifluvents; $46 \%$ sand, $39 \%$ silt, $15 \%$ clay, $0.89 \%$ organic matter, and $\mathrm{pH} 7.4$ ) in 1998 and Imperial-Glenbar clay loam $(59 \%$ sand, $31 \%$ silt, and $10 \%$ clay, 1.07 organic matter, and $\mathrm{pH}$ 7.4) in 1999. At the San Joaquin Valley sites, soils were Hesperia loamy sand (coarse-loamy, mixed, nonacid thermic Xerioc Torriorthents; $69 \%$ sand, $19 \%$ silt, $12 \%$ clay, 0.52 organic matter, and $\mathrm{pH} 7.2$ ) in 1998 and Cajon fine sandy loam (mixed, thermic Typic Torripsamments; $86 \%$ sand, $9 \%$ silt, $5 \%$ clay, 0.36 organic matter, and $\mathrm{pH} 5.2$ ) in 1999.

The experimental design was a random- ized complete block with four replications. Individual plots were $1.5 \mathrm{~m}$ wide $\times 6.1 \mathrm{~m}$ long. Carrots were direct seeded in six lines per raised bed with a commercial carrot planter. Cultural practices and crop management followed typical commercial practices for the area (McGiffen, 1997). The treatments included 


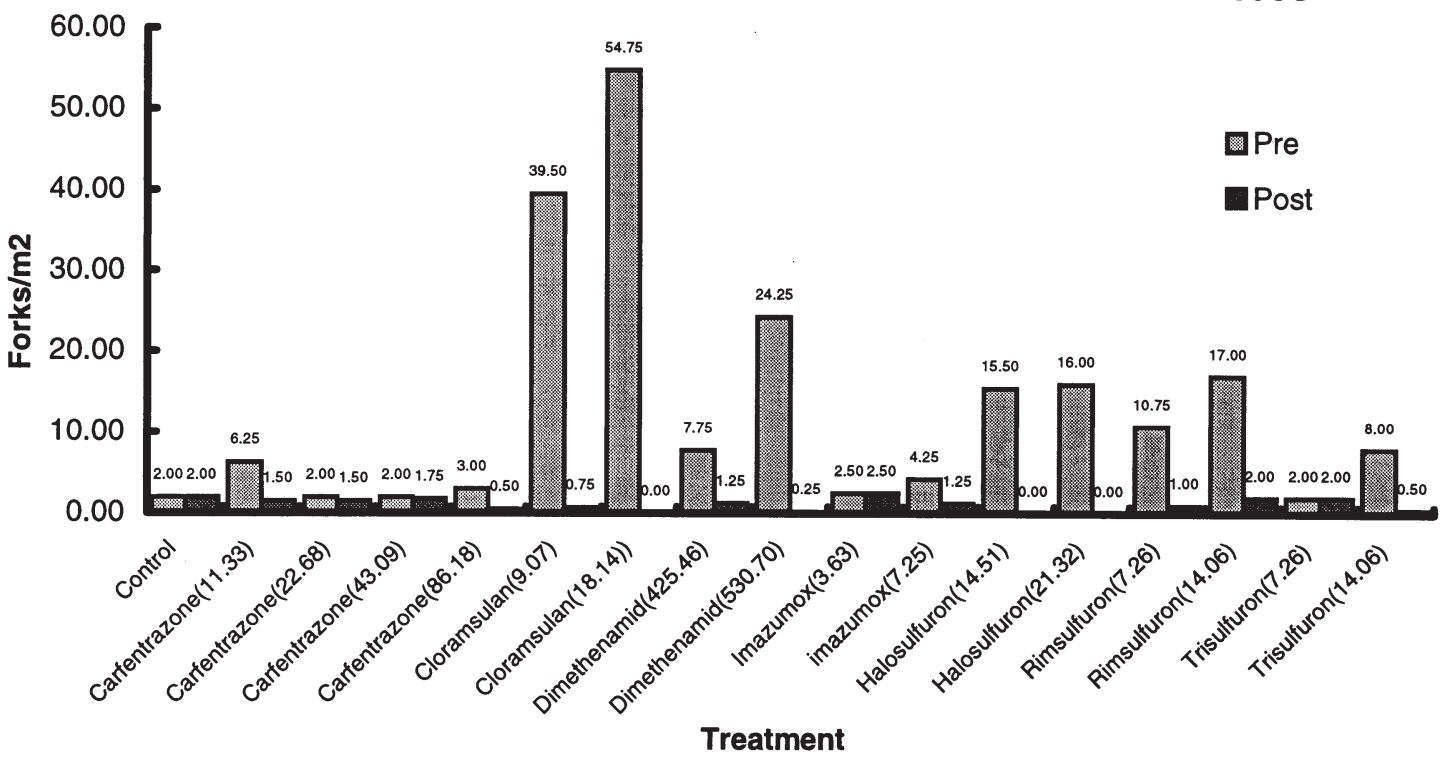

1999

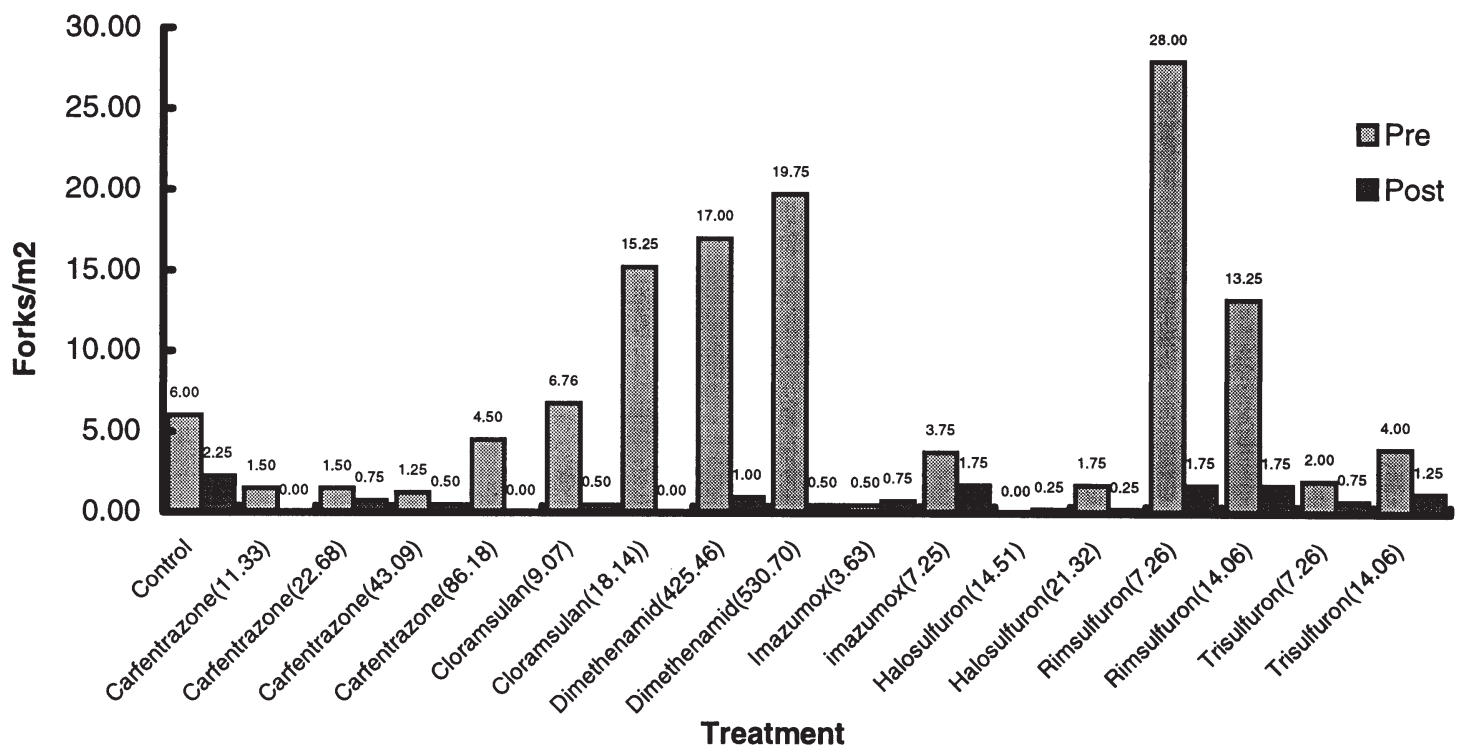

Fig. 1. Effect of PRE or POST herbicide applications on carrot (Caropak) root forking at the San Joaquin Valley Site.

untreated control, carfentrazone, cloransulam, sulfentrazone, dimethenamid, imazamox, halosulfuron, rimsulfuron, and triflusulfuron applied preemergence (PRE) immediately after carrot was seeded, or postemergence (POST) $\approx 2$ weeks after crop emergence (Table 1). PRE applications were made on 24 Aug. 1998 and 12 Aug. 1999 in the San Joaquin Valley, and 19 Oct. 1998 and 8 Oct. 1999 in the Imperial Valley. POST herbicides were applied on 17 Sept. 1998 and 20 Sept. 1999 in the San Joaquin Valley, and 24 Nov. 1998 and 18 Nov. 1999 in the Imperial Valley. All herbicides were sprayed over the top of each plot with a $\mathrm{CO}_{2}$ backpack sprayer equipped with 8003 nozzles delivering $185 \mathrm{~L} \cdot \mathrm{h}^{-1}$ of spray solution.

Four variables were used to evaluate carrot tolerance to herbicides: visual damage, carrot top weight, marketable weight, and the number of forked roots. Visual crop injury assessments were taken 4 and 8 weeks after treatment. A visual scale of 0 to 10 was used, in which $0=$ no crop damage, and $10=$ death of the carrot plant (Tables 2 and 3). Carrots were harvested at maturity, on 14 Jan. 1999 and 20 Jan. 2000 for San Joaquin Valley. The Imperial Valley experiment was harvested on 1 Apr. 1999 and 13 Apr. 2000. Carrot tops and roots from a square meter area were evaluated for possible damages or reduction due to herbicide application. Marketable roots and those with defects such as forks were counted and weighed. The data were subjected to analysis of variance and means separated using least significant difference at $P \leq 0.05$ using SAS Proc GLM (SAS Institute, 1998).

\section{Results and Discussion}

San Joaquin Valley carrots were generally more tolerant of PRE herbicide applications than of POST ones. PRE ratings were slightly high at 4 weeks, but declined by the 8 -week ratings. Neither PRE application of carfentrazone damaged carrots during the 1998 season (Table 2), but both rates slightly injured shoots in 1999 (Table 3). Carrots also tolerated PRE applications of imazamox and triflusulfuron with minimal injury in 1998 and 1999. The effect of rimsulfuron at 7.3 and $14.1 \mathrm{~g} \cdot \mathrm{ha}^{-1}$ varied greatly between the 2 years, with an injury rating of 1.0 and 0.50 in 1998 and severe injury that ranged from 7.0 to 9.5 in 1999 . Carrots were very tolerant of either PRE rate of dimethenamid in 1998, but were injured by the same treatments in 1999. Cloransulam and halosulfuron severely damaged carrot, irrespective of the rate or the application timing. The injuries due to low rates of cloransulam and halosulfuron were 2.0 and 3.3 by the 8 week rating in 1998, but were lethal (9.3 and 10.0) in 1999.

Carrots were more tolerant of either rate of 
Table 4. The effect of rates and timing of different herbicides on carrot (Caropak) injury and yield in the Imperial Valley in 1998. Applications were made after carrot planting (PRE) or after seedling emergence and establishment (POST). Injury was recorded on a visual scale of 0 to 10, where $0=$ no crop damage, and $10=$ death of carrot plant.

\begin{tabular}{|c|c|c|c|c|c|c|c|c|c|c|c|}
\hline \multirow[b]{4}{*}{ Treatment } & \multirow{4}{*}{$\begin{array}{c}\text { Rate } \\
\left(\mathrm{g} \cdot \mathrm{ha}^{-1} \text { a.i. }\right)\end{array}$} & \multirow{2}{*}{\multicolumn{4}{|c|}{ Weeks after treatment }} & \multicolumn{6}{|c|}{ Carrot yield } \\
\hline & & & & & & \multirow{2}{*}{\multicolumn{2}{|c|}{$\begin{array}{c}\text { Top wt } \\
\left(\mathrm{t} \cdot \mathrm{h}^{-1}\right)\end{array}$}} & \multirow{2}{*}{\multicolumn{2}{|c|}{$\begin{array}{l}\text { No. of marketable } \\
\qquad\left(\mathrm{M}^{2}\right)\end{array}$}} & \multirow{2}{*}{\multicolumn{2}{|c|}{$\begin{array}{c}\text { Marketable wt } \\
\left(\mathrm{t}^{-} \cdot \mathrm{ha}^{-1}\right)\end{array}$}} \\
\hline & & \multicolumn{2}{|c|}{4 weeks } & \multicolumn{2}{|c|}{8 weeks } & & & & & & \\
\hline & & $\overline{\text { PRE }}$ & $\overline{\text { POST }}$ & $\overline{\text { PRE }}$ & $\overline{\text { POST }}$ & $\overline{\text { PRE }}$ & POST & PRE & POST & $\overline{\text { PRE }}$ & POST \\
\hline Control & N/A & 0.0 & 0.0 & 0.0 & 0.0 & 6.0 & 5.9 & 69.3 & 54.5 & 9.9 & 6.1 \\
\hline Carfentrazone & 11.3 & 0.0 & 3.5 & 0.3 & 1.5 & 5.4 & 5.3 & 98.0 & 81.8 & 10.3 & 9.1 \\
\hline Carfentrazone & 22.7 & 0.8 & 7.3 & 0.5 & 6.0 & 5.4 & 4.2 & 85.3 & 58.8 & 9.8 & 8.1 \\
\hline Sulfentrazone & 43.1 & 0.0 & 2.0 & 0.0 & 0.3 & 6.1 & 5.6 & 81.0 & 76.0 & 9.2 & 9.0 \\
\hline Sulfentrazone & 86.2 & 0.0 & 2.5 & 0.0 & 0.9 & 6.4 & 5.9 & 98.3 & 61.8 & 10.3 & 9.7 \\
\hline Cloransulam & 9.1 & 5.3 & 4.3 & 4.5 & 5.8 & 3.8 & 4.3 & 16.8 & 13.8 & 1.7 & 1.8 \\
\hline Cloransulam & 18.1 & 7.0 & 4.3 & 5.8 & 8.5 & 3.3 & 2.7 & 6.8 & 7.8 & 0.7 & 0.8 \\
\hline Dimethenamid & 425.5 & 1.5 & 2.5 & 0.8 & 1.1 & 4.8 & 4.5 & 30.3 & 60.8 & 2.9 & 6.4 \\
\hline Dimethenamid & 530.7 & 2.0 & 2.5 & 1.5 & 2.1 & 5.9 & 4.2 & 38.0 & 65.0 & 6.6 & 7.3 \\
\hline Imazamox & 3.6 & 0.0 & 0.0 & 0.0 & 0.0 & 6.3 & 5.8 & 115.8 & 87.3 & 12.5 & 10.1 \\
\hline Imazamox & 7.3 & 0.0 & 0.0 & 0.0 & 0.0 & 5.8 & 5.9 & 82.0 & 88.8 & 8.3 & 8.5 \\
\hline Halosulfuron & 14.5 & 3.8 & 3.5 & 2.5 & 9.0 & 4.7 & 1.9 & 17.0 & 14.8 & 6.9 & 1.6 \\
\hline Halosulfuron & 21.3 & 5.3 & 4.0 & 4.0 & 9.0 & 4.0 & 1.9 & 32.0 & 7.8 & 2.1 & 0.7 \\
\hline Rimsulfuron & 7.3 & 0.8 & 3.5 & 0.5 & 6.3 & 5.8 & 4.1 & 66.8 & 35.8 & 7.6 & 4.0 \\
\hline Rimsulfuron & 14.1 & 1.0 & 4.5 & 0.8 & 8.5 & 6.2 & 2.4 & 45.8 & 23.0 & 4.9 & 2.5 \\
\hline Triflusulfuron & 7.3 & 0.0 & 1.3 & 0.0 & 2.9 & 6.9 & 5.8 & 111.8 & 49.3 & 11.1 & 5.7 \\
\hline Trifusulfuron & 14.1 & 0.0 & 2.0 & 0.0 & 6.0 & 6.8 & 4.7 & 128.8 & 46.8 & 13.1 & 5.2 \\
\hline LSD @ $\alpha=0.05$ & N/A & 0.4 & 0.4 & 0.4 & 0.2 & 1.5 & 1.4 & 31.7 & 17.8 & 4.4 & 1.9 \\
\hline
\end{tabular}

Table 5. The effect of rates and timing of different herbicides on carrot (Caropak) injury and yield in the Imperial Valley in 1999. Applications were made after carrot planting (PRE) or after seedling emergence and establishment (POST). Injury was recorded on a visual scale of 0 to 10, where $0=$ no crop damage, and $10=$ death of carrot plant.

\begin{tabular}{|c|c|c|c|c|c|c|c|c|c|c|c|}
\hline \multirow[b]{4}{*}{ Treatment } & \multirow{4}{*}{$\begin{array}{c}\text { Rate } \\
\left(\mathrm{g} \cdot \mathrm{ha}^{-1} \text { a.i. }\right)\end{array}$} & & & & & \multicolumn{6}{|c|}{ Carrot yield } \\
\hline & & \multicolumn{4}{|c|}{ Weeks after treatment } & \multirow{2}{*}{\multicolumn{2}{|c|}{$\begin{array}{c}\text { Top wt } \\
\left(\mathrm{t} \cdot \mathrm{h}^{-1}\right)\end{array}$}} & \multirow{2}{*}{\multicolumn{2}{|c|}{$\begin{array}{c}\text { No. of marketable } \\
\left(\mathrm{M}^{2}\right)\end{array}$}} & \multirow{2}{*}{\multicolumn{2}{|c|}{$\begin{array}{l}\text { Marketable wt } \\
\left(\mathrm{t} \cdot \mathrm{ha}^{-1}\right)\end{array}$}} \\
\hline & & \multicolumn{2}{|c|}{4 weeks } & \multicolumn{2}{|c|}{8 weeks } & & & & & & \\
\hline & & $\overline{\text { PRE }}$ & $\overline{\text { POST }}$ & PRE & $\overline{\text { POST }}$ & $\overline{\text { PRE }}$ & POST & PRE & POST & PRE & POST \\
\hline Control & N/A & 0.0 & 0.0 & 0.0 & 0.0 & 5.2 & 4.8 & 54.8 & 55.3 & 11.2 & 10.3 \\
\hline Carfentrazone & 11.3 & 0.0 & 6.8 & 0.0 & 4.3 & 4.7 & 3.3 & 54.5 & 69.5 & 11.0 & 12.2 \\
\hline Carfentrazone & 22.7 & 0.0 & 8.0 & 0.0 & 6.3 & 5.3 & 2.8 & 47.0 & 63.3 & 9.1 & 10.4 \\
\hline Sulfentrazone & 43.1 & 0.0 & 5.0 & 0.0 & 4.0 & 4.5 & 3.0 & 50.0 & 61.5 & 9.3 & 10.2 \\
\hline Sulfentrazone & 86.2 & 0.3 & 5.8 & 0.0 & 2.8 & 5.2 & 4.3 & 54.5 & 65.0 & 10.5 & 12.0 \\
\hline Cloransulam & 9.1 & 6.5 & 4.0 & 6.0 & 5.3 & 2.1 & 3.6 & 1.0 & 29.0 & 0.2 & 4.8 \\
\hline Cloransulam & 18.1 & 7.3 & 5.5 & 8.3 & 9.3 & 1.2 & 1.5 & 0.0 & 15.5 & 0.0 & 2.2 \\
\hline Dimethenamid & 425.5 & 7.5 & 2.1 & 7.0 & 2.9 & 3.9 & 4.2 & 19.8 & 35.8 & 3.0 & 7.7 \\
\hline Dimethenamid & 530.7 & 8.0 & 3.3 & 8.0 & 1.0 & 4.0 & 4.9 & 18.5 & 46.8 & 2.8 & 8.4 \\
\hline Imazamox & 3.6 & 0.0 & 0.1 & 0.0 & 0.0 & 5.3 & 5.1 & 58.0 & 60.3 & 12.0 & 12.2 \\
\hline Imazamox & 7.3 & 0.1 & 0.8 & 0.0 & 0.4 & 5.8 & 5.0 & 45.8 & 59.3 & 9.3 & 10.9 \\
\hline Halosulfuron & 14.5 & 7.8 & 6.0 & 8.8 & 10.0 & 3.3 & 1.3 & 0.3 & 7.5 & 0.1 & 1.5 \\
\hline Halosulfuron & 21.3 & 7.5 & 6.5 & 8.1 & 10.0 & 3.0 & 0.6 & 13.0 & 3.8 & 0.1 & 0.5 \\
\hline Rimsulfuron & 7.3 & 0.8 & 3.3 & 0.1 & 7.0 & 5.1 & 3.3 & 39.0 & 6.0 & 7.5 & 1.1 \\
\hline Rimsulfuron & 14.1 & 3.0 & 4.3 & 1.6 & 9.0 & 4.5 & 2.4 & 12.5 & 24.8 & 2.2 & 3.4 \\
\hline Triflusulfuron & 7.3 & 0.1 & 2.8 & 0.1 & 6.0 & 4.0 & 3.5 & 49.3 & 20.0 & 9.5 & 3.5 \\
\hline Trifusulfuron & 14.1 & 0.4 & 3.3 & 0.0 & 6.8 & 4.3 & 3.1 & 37.0 & 17.0 & 6.3 & 2.9 \\
\hline LSD @ $\alpha=0.05$ & N/A & 0.4 & 0.4 & 0.4 & 0.2 & 1.5 & 1.4 & 31.7 & 17.8 & 4.4 & 1.9 \\
\hline
\end{tabular}

imazamox than any other POST treatment in both 1998 and 1999. In 1998, POST imazamox applied at $3.6 \mathrm{~g} \cdot \mathrm{ha}^{-1}$ had an injury rating of 1.8 in 4 weeks that declined to 1.00 in the 8 -week rating. POST imazamox applied at $7.3 \mathrm{~g} \cdot \mathrm{ha}^{-1}$ had an injury rating of 3.5 for the 4 -week rating but decreased to 0.8 in the 8 -week rating (Table 2). The 1999 data followed the same trend of slight injury from either rate of POST imazamox early in the season that carrots completely recovered from by the end of the season (Table 3).

San Joaquin Valley carrot yields for the PRE treatments were different from the visual injury ratings. It appears that the visual treatment effect on carrot tops did not necessarily correlate with root yield. Carrot tops, number and weight of marketable in PREcarfentrazone, imazamox, triflusulfuron and dimethenamid treatments were equivalent to those in the untreated control plots in 1998 (Table 2). All other PRE treatments reduced carrot top weight in 1998. The number of marketable roots in 1998 had mixed results for the PRE treatments. The high rate of carfentrazone was the only PRE treatment that did not decrease the number of marketable roots, and all POST applications reduced the number of marketable roots in 1998.

Marketable root weights were unaffected by the $22.7 \mathrm{~g} \cdot \mathrm{ha}^{-1}$ a.i. carfentrazone and the 3.6 $\mathrm{g} \cdot \mathrm{ha}^{-1}$ a.i. imazamox PRE treatments (Table 2). Most of the other PRE treatments caused some reductions in root yield, with severe reductions for either rate of cloransulam and the high rate of halosulfuron. Sulfentrazone, cloransulam, the high rate of dimethenamid and halosulfuron treatments severely reduced carrot top and root weight and the number of marketable roots (Table 2). The number of forked roots was high when high rates of PRE treatments were used. Both the high and low rates of cloransulam and the high rate of dimethenamid, rimsulfuron, and halosulfuron greatly increased the number of forked roots in 1998. POST herbicide applications did not affect forking in either year (Fig. 1).

In 1999, top weights from the low rate PRE application of carfentrazone, triflusulfuron, and both rates of imazamox were the only treatments comparable to the untreated control. POST imazamox and triflusulfuron were the only treatments that did not reduce carrot top weight in 1999 (Table 3). All the PRE treatments decreased marketable root weight in 1999; however, the imazamox treatments, and the low rate of triflusulfuron did not affect the number of marketable roots. Both PRE rates of imazamox, triflusulfuron, carfentrazone, and the low rate of sulfentrazone caused some 




1999

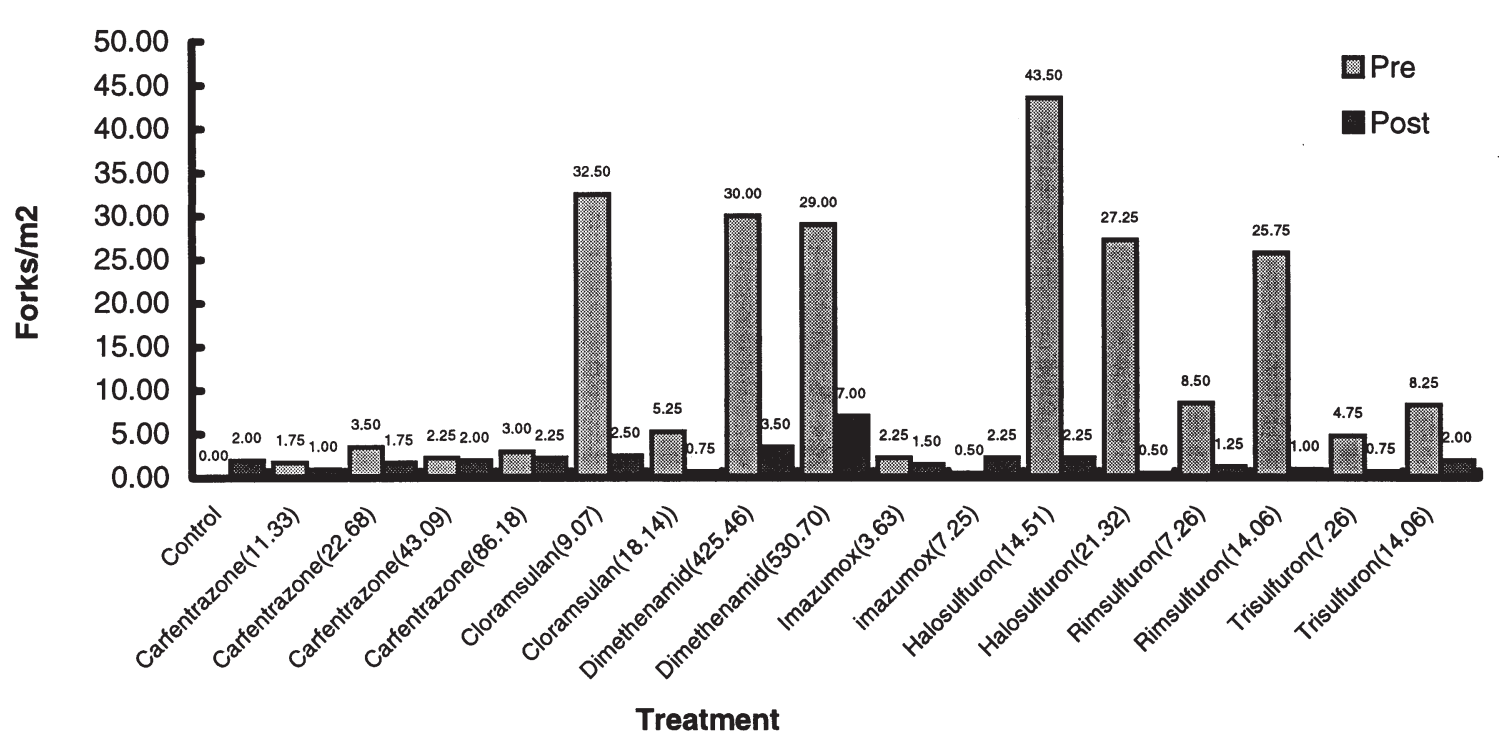

Fig. 2. Effect of PRE or POST herbicide applications on carrot (Caropak) root forking at Imperial Valley site.

reduction in the number of marketable roots. There were few marketable roots for either PRE application rate of chloramsulan, dimethenamid, halosulfuron, or rimsulfuron. The POST imazamox treatments, triflusulfuron, and the low rate of rimsulfuron had marketable root weights comparable to the untreated control (Table 3). Both POST rates of chloramsulan and halosulfuron severely reduced marketable root yield.

Carrot root weights varied across treatments in 1999. Several herbicides, notably imazamox and triflusulfuron, had yields comparable to or slightly greater than the untreated control plots (Table 3 ). For 3.6 or $7.3 \mathrm{~g} \cdot \mathrm{ha}^{-1}$ imazamox PRE, carrot root weight was 6.0 and $6.7 \mathrm{t} / \mathrm{ha}$ respectively. Triflusulfuron PRE applied at 7.3 and $14.1 \mathrm{~g} \cdot \mathrm{ha}^{-1}$ had roots weights of 7.0 and $5.7 \mathrm{t} \cdot \mathrm{ha}^{-1}$ compared to $7.0 \mathrm{t} \cdot \mathrm{ha}^{-1}$ for the untreated control (Table 3). Imazamox and the low rate of triflusulfuron were the only POST herbicides that did not reduce root weight in the San Joaquin Valley in 1999. The low rate triflusulfuron treatment had a root weight of $7.0 \mathrm{t}^{-h^{-1}}$ (Tables 3) with a low number of forked roots in 1999, but with more forking at the high rate. POST herbicides did not affect forking in 1999.

Imperial Valley carrots were more tolerant of PRE herbicide applications than the POST treatments at the Imperial Valley site. PRE application of carfentrazone, sulfentrazone, imazamox, triflusulfuron and rimsulfuron caused no injury to carrot during 1998 or 1999. Injury ratings were generally moderate at 4 weeks but decreased later in the season.
In 1998, crop injury ranged from zero to a low 0.8 visual rating for PRE applications of carfentrazone, sulfentrazone, imazamox, and triflusulfuron (Table 4). Injury due to the high rate of rimsulfuron in 1999 was high for the 4-week rating but later decreased to a moderate 1.6 by the 8 -week rating. Triflusulfuron applied at $14.1 \mathrm{~g} \cdot \mathrm{ha}^{-1}$ did not injure carrot at the 4- or 8-week rating in 1999. Halosulfuron and cloransulam caused more injury to carrots in 1999 than in 1998 irrespective of the timing or rates of application (Table 5). Neither rate of imazamox caused injury to carrots when applied POST and imazamox was the only safe POST treatment in 1998 and 1999.

Yield data and injury followed the same trend for PRE treatments in the Imperial Valley. The carrot top weight, number of marketable 
roots, and root weight were similar to the untreated control for PRE applications of carfentrazone, imazamox, sulfentrazone, and triflusulfuron (Table 4). POST carfentazone, sulfentrazon, triflusulfuron, and imazamox had top weights that were comparable to the untreated control. The number of PRE marketable roots for these treatments ranged from a low of 66.8 to a high 115.8 per square meter compared to 69.1 per square meter of the untreated control.

The number of marketable roots for POST carfentrazone, sulfentrazone, dimethenamid and imazamox were also equivalent to the untreated control (Table 4). The number of forked roots due to injury from PRE treatments varied, with high numbers of forked roots for both rates of cloramsulan and halosulfuron, and the high rate of dimethenamid and rimsulfuron (Fig. 2). In 1998, POST imazamox, carfentrazone, and sulfentrazone did not affect root weight. All other POST applied herbicides decreased yield in the Imperial Valley experiment in 1998 (Table 4).

In 1999, the effect of PRE applications on carrot top weight, number of marketable roots, and root weight followed the same trend as in 1998, where carrots tolerated carfentrazone, imazamox, rimsulfuron, and triflusulfuron, and were injured by both rates of cloransulam, halosulfuron, and dimethenamid. The only POST treatments that did not affect carrot top weight were dimethenamid and imazamox (Table 5). POST herbicide applications did not affect forking in 1999 (Fig. 2).

The number of marketable roots was equivalent to the untreated control for the high and low rate PRE treatments for carfentrazone, sulfentrazone, imazamox, triflusulfuron and rimsulfuron (Table 5). Among the POST treatments tested, the number of roots in plots treated with either rate of carfentrazone, sulfentrazone, and imazamox were not different from the untreated control. Carrot root weight was unaffected by either rate of carfentrazone, sulfentrazone or imazamox (Table 5).

Carrot tolerated only a few herbicides in the San Joaquin Valley experiment, with PRE applications causing less injury than POST applications. Carrot in the Imperial Valley site tolerated more herbicides, including carfentrazone, imazamox, and sulfentrazone. Sulfentrazone applied either PRE or POST did not reduce carrot yield in the Imperial Valley, but injured and reduced the weight of carrot in the San Joaquin Valley. The differences in the soil textures, irrigation method, monthly rainfall and temperature may have affected how carrot reacts to the same herbicides in two different locations. Temperature and soil characteristics are known to affect herbicide activity and crop sensitivity (Haar et al., 2002). Temperatures were similar for both sites, but precipitation was much less in the Imperial Valley than the San Joaquin. In 1998, the total monthly rainfall in San Joaquin Valley from planting to the harvest was $174 \mathrm{~mm}$ compared with $33 \mathrm{~mm}$ recorded for Imperial Valley. In 1999, total rainfall was again much greater for the San Joaquin site $(123 \mathrm{~mm})$ than the Imperial Valley $(23 \mathrm{~mm})$ (Table 1). Irrigation systems for growing carrot were also different in these locations. Irrespective of rates of application and timing, carrot grown in either the San Joaquin or Imperial Valleys tolerated imazamox and triflusulfuron.

\section{Literature Cited}

Bell, C.E., B.E. Boutwell, E.J. Ogbuchiekwe, and M.E. McGiffen. 2000a. Weed control in carrot: The efficacy and economic value of linuron. HortScience 35(6):1089-1091.

Bell, C.E, S.A Fennimore, M.E McGiffen, Jr., W.T. Lanini, D.W. Monks, J.B. Masiunas, A.R. Bannannos, B.H. Zandstra, K.Umeda, W.M. Stall, R.R. Bellinder, R.D. William, and R.B. McReynolds. 2000b. My view. Weed Sci. $48: 1$.

Harr, M.J., S.A. Fennimore, M.E. McGiffen, W.T. Lanini, and C.E. Bell. 2002. Evaluation of Preemergence herbicides in vegetable crops. HortTechnology 12(1):95-99

McGiffen, M.E., J. Nunez, T. Suslow, and K.M. Mayberry. 1997. Carrot production in California. Vegetable Res. Info. Ctr., Veg. Prod. Ser. Univ. of California, Div. Agr. Natural Resources. Coop. Ext. Publ. 7226.

SAS Institute. 1998. SAS/STAT user's guide. Vers. 8.00. SAS Inst., Cary, N.C

Stall, W.M. and J.A. Dusky. 2000. Weed control in carrots and parsley. 7 July 2000. http://www. edis.ifas.ufledu .

U.S. Dept. of Agriculture (USDA)/National Agricultural Statistics Service. 2000a. Statistics of vegetables and melons. 1 June 2000. http://www. usda.gov/nass/pubs/agr00/00_ch4.pdf.

U.S. Dept. of Agriculture (USDA). 2000b Crop profile for carrots in California. 1 Jan. 2000. http://pestdata.ncsu.edu/cropprofiles/docs/CAcarrot.html.

U.S. Dept. of Agriculture (USDA) 2001. Crop values summary. 1 Feb. 2001. http://usda. mannlib.comell.edu/reports/nassr/price/zcvbb/cpv10202.pdf. 